DARWIN's BARDS

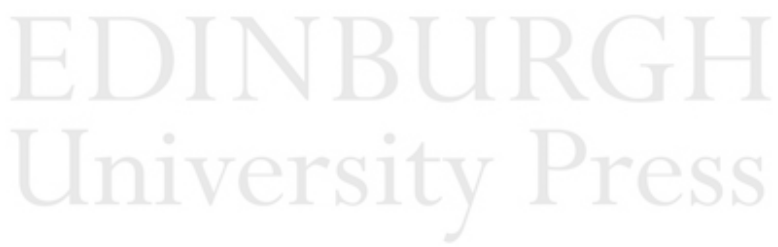


To Jo,

Amy and Hannah

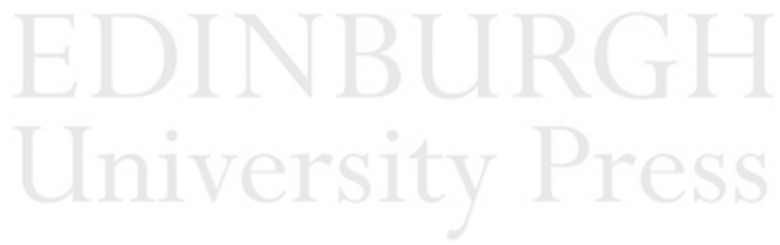




\title{
DARWIN'S BARDS
}

British and American Poetry in the Age of Evolution

\author{
John Holmes
}

Edinburgh University Press 
(C) John Holmes, 2009

Edinburgh University Press Ltd

22 George Square, Edinburgh

www.euppublishing.com

Typeset in 11/13 pt Goudy Old Style

by Servis Filmsetting Ltd, Stockport, Cheshire, and printed and bound in Great Britain by

CPI Antony Rowe Ltd, Chippenham and Eastbourne

A CIP record for this book is available from the British Library

ISBN 9780748639403 (hardback)

The right of John Holmes

to be identified as author of this work

has been asserted in accordance with

the Copyright, Designs and Patents Act 1988. 